\title{
Analisis parameter fisika kimia kualitas perairan di Sungai Krueng Mane
} Aceh Utara

\section{[Analysis of physical and chemical parameters of water quality in the Krueng Mane River, Aceh Utara]}

\author{
Irfannur $^{1}$, Khairan $^{1^{*}}$
}

\section{${ }^{1}$ Program Studi Akuakultur, Fakultas Pertanian Universitas Almuslim. Jln. Almuslim Matangglumpangdua, Bireuen-Aceh}

ABSTRACT |This study aims to determine the quality of river water with the level of waste pollution in the Kreung Manee river, Aceh Utara. There are 3 research stations. The parameters tested were temperature, turbidity and brightness measurements using the in situ method, to measure $\mathrm{pH}$, dissolved oxygen, COD and ammonia levels referring to the water quality standards from SNI.06-6989.14 (2009) and the pollution index. The results of research conducted in the waters of the Krueng Mane river in North Aceh have an average temperature measurement value between $29 \mathrm{oC}-30 \mathrm{oC}$, dissolved oxygen between $5.7 \mathrm{mg} / \mathrm{l}-6.5$ $\mathrm{mg} / \mathrm{l}$, brightness between $63 \mathrm{~cm}-80 \mathrm{~cm}$, nitrate between $0.024 \mathrm{mg} / \mathrm{l}-0.027 \mathrm{mg} / \mathrm{l}$, phosphate between $0.06 \mathrm{mg} / \mathrm{l}-0.11 \mathrm{mg} / \mathrm{l}, \mathrm{pH}$ between $8.23-8.68$, Chemycal Oxygen Demand (COD) between $48.528 \mathrm{mg} / \mathrm{l}$ $87.437 \mathrm{mg} / \mathrm{l}$, it can be concluded that the water quality parameters in the waters of the Krueng Mane river, Aceh Utara, are still included in the medium pollution category. The condition of the quality of the waters of the Krueng Mane river in North Aceh is still suitable for living things.

Key words | Water quality, Krueng Mane, rivers, pollution

ABSTRAK | Penelitian ini bertujuan untuk mengetahui kualitas air sungai dengan tingkatan pencemaran limbah di sungai Kreung Manee Aceh Utara. Stasiun penelitian berjumlah 3 stasiun. Parameter yang di uji adalah pengukuran suhu, kekeruhan dan kecerahan menggunakan metode in situ, untuk mengukur kadar $\mathrm{pH}$, oksigen terlarut, COD dan amoniak mengacu pada baku mutu air dari SNI.06-6989.14 (2009) serta indek pencemaran. Hasil penelitian yang dilakukan di perairan sungai Krueng Mane Aceh Utara memiliki nilai rata-rata pengukuran suhu antara $29^{\circ} \mathrm{C}-30^{\circ} \mathrm{C}$, oksigen terlarut antara $5,7 \mathrm{mg} / \mathrm{l}-6,5 \mathrm{mg} / \mathrm{l}$, kecerahan antara $63 \mathrm{~cm}-80 \mathrm{~cm}$, nitrat antara $0,024 \mathrm{mg} / \mathrm{l}-0.027 \mathrm{mg} / \mathrm{l}$, phospat antara $0,06 \mathrm{mg} / \mathrm{l}-0,11 \mathrm{mg} / \mathrm{l}$, pH antara 8,23 - 8,68, Chemycal Oxygen Demand (COD) antara 48,528 mg/l - 87,437 mg/l, dapat disimpulkan bahwa parameter kualitas perairan di perairan sungai Krueng Mane Aceh Utara masih termasuk pada kategori pencemaran sedang. Kondisi kualitas perairan sungai Krueng Mane Aceh Utara masih bisa untuk kehidupan makhluk hidup.

Kata kunci | Kualitas air, Krueng Mane, sungai, pencemaran

Received | 28 April 2021, Accepted | 20 Mei 2021, Published | 31 Mei 2021.

*Koresponden| Khairan, Program Studi Akuakultur, Fakultas Pertanian Universitas Almuslim. Jln. Almuslim Matangglumpangdua, Bireuen-Aceh. Email: khairan@gmail.com

Kutipan| Irfannur, I., \& Khairan, K. (2021). Analisis parameter fisika kimia kualitas perairan di Sungai Krueng Mane Aceh Utara. Arwana: Jurnal IImiah Program Studi Perairan, 3(1), 16-23.

p-ISSN (Media Cetak) | 2657-0254

e-ISSN (Media Online) | 2797-3530 yang didistribusikan di bawah syarat dan ketentuan Creative Commons Attribution-ShareAlike 4.0 International License.

\section{PENDAHULUAN}

Sungai berfungsi sebagai wadah pengaliran air selalu berada di posisi paling rendah dalam landskap bumi. Oleh karena itu kondisi sungai tidak dapat dipisahkan dari kondisi Daerah Aliran Sungai (PP 38 Tahun 2011). Perubahan pola pemanfaatan sungai menjadi lahan pembuangan limbah cair kelapa sawit seiring meningkatnya aktivitas industri pengolahan kelapa sawit yang memberikan dampak terhadap kondisi biologis dan hidrologis dalam suatu Daerah Aliran Sungai (DAS). Perubahan pola pemanfaatan sungai berarti telah terjadi 
perubahan terhadap jumlah organisme yang berada dalam sungai Krueng Manee.

Limbah cair juga dihasilkan pada proses pengolahan kelapa sawit terutama dari centrifuge waste dan claybath waste. Limbah cair ini apabila dibuang keperairan akan mengakibatkan perubahan sifat fisika, kimia, dan biologi perairan sehingga akan merusak lingkungan. Limbah cair industri minyak kelapa sawit mengandung bahan organik yang sangat tinggi yaitu Biochemycal Oxigen Demand (BOD) $25.500 \mathrm{mg} / \mathrm{l}$, Chemycal Oxygen Demand (COD) $48.000 \mathrm{mg} / \mathrm{l}$, TSS $31.170 \mathrm{ml} / \mathrm{l}, \mathrm{N} 41 \mathrm{ml} / \mathrm{l}$, minyak dan lemak $3.075 \mathrm{ml} / \mathrm{l}$ dan $\mathrm{pH} 4,0$ dan menjadi berbahaya apabila dibuang langsung ke perairan tanpa proses pengolahan terlebih dahulu (Syafriadiman, 2016).

Parameter kualitas perairan memegang peranan penting terhadap dalam kehidupan sehari-hari sebagai kebutuhan hidup manusia. Air banyak dimanfaatkan dalam kehidupan sehari-hari. Oleh sebab demikian kualitas perairan sangat penting untuk diperhatikan, terlebih lagi sumber air yang mempunyai ruang lingkup yang lebih luas seperti sungai yang menjadi sumber air bagi manusia juga menjadi media kehidupan beraneka ragam organisme perairan. Terjadinya pencemaran pada badan air termasuk sungai akan mengganggu kehidupan normal organisme yang berada di sungai tersebut. Dengan adanya pencemaran air menyebabkan menurunnya kuaitas perairan, sehingga daya dukung perairan tersebut terhadap organisme fitoplankton yang hidup di dalamnya akan menurun (Akmal et al., 2021). Kelimpahan fitoplankton yang terdapat dalam sungai Krueng Manee Aceh Utara terdapat pada Stasiun 2 sebesar 71292 ind/L dan terendah terdapat pada Stasiun 1 sebesar $39081 \mathrm{ind} / 1$ (Habibi, 2020), sedangkan kelimpahan zooplankton tertinggi terdapat pada Stasiun 3 sebesar 1561 ind/l (Amrizal, 2020).

Masalah pencemaran perairan menimbulkan berbagai akibat, baik yang bersifak biologik, fisik maupun kimia. Akibat biologik yang terlihat jelas di perairan antara lain berupa kematian ikan atau sekurang-kurangnya berupa kelainan struktural maupun fungsional ke arah abnormal. Untuk perubahan fisik seperti perubahan terhadap warna dan bau yang ditimbulkan dari air, sedangkan untuk perubahan kimia dapat teridentifikasi dengan adanya pengukuran terhadap parameter seperti
pH, Chemycal Oxygen Demand (COD), Biochemycal Oxigen Demand (BOD), suhu, oksigen terlarut, karbondioksida dan amoniak (Agustiningsih et al., 2012).

Sungai yang berada di Krueng Manee Aceh Utara menjadi lahan pembuangan limbah cair kelapa sawit dari pabrik pengolahan kelapa sawit yang berada dekat dengan sungai. Limbah cair buangan pabrik kelapa sawit adalah hasil sampingan dari suatu proses kegiatan industri yang menggunakan air per satuan waktu atau per satuan bahan baku (produksi), biasa di ukur dalam satuan liter per detik, meter kubik per jam, meter kubik per bahan baku, dan meter kubik per produksi. Buangan limbah kelapa sawit yang mengalir langsung ke sungai membuat perubahan terhadap sifat fisik, kimia dan biologi suatu perairan. Perubahan yang terjadi pada perairan sungai dapat mempengaruhi terhadap organisme perairan yang berada dalam sungai tersebut. Pencemaran lingkungan perairan sungai yang terjadi akibat adanya pembuangan limbah kelapa sawit yang dapat mencemari perairan sungai dan mengganggu pertumbuhan dan kelangsungan hidup organisme perairan tersebut. Tujuan dari penelitian ini adalah: untuk mengetahui pengaruh limbah cair kelapa sawit terhadap kualitas air sungai Krueng Manee Aceh Utara. Untuk mengetahui tingkatan pencemaran limbah cair kelapa sawit terhadap sungai Kreung Manee Aceh Utara.

\section{BAHAN DAN METODE}

Penelitian dilaksanakan di perairan sungai Kreung Mane. Stasiun penelitian berjumlah 3 stasiun, stasiun I terletak pada koordinat $5^{\circ} 23^{\prime} 50,7^{\prime \prime} \mathrm{LU}-96^{\circ} 90^{\prime} 952,3^{\prime \prime} \mathrm{BT}$. Lokasi ini adalah lokasi kontrol yang terletak di aliran sungai yang belum tercemar dengan limbah cair kelapa sawit. Stasiun II terletak pada koordinat $5^{\circ} 23^{\prime} 52,2^{\prime \prime} \mathrm{LU}$ - 96²0'83,5"BT. Lokasi ini merupakan daerah awal dari badan sungai yang terkena limbah cair kelapa sawit. Stasiun III terletak pada koordinat $5^{\circ} 23^{\prime} 67,76^{\prime \prime} \mathrm{LU}$ $96^{\circ} 90^{\prime} 80,1^{\prime \prime B T}$. Lokasi initerletak pada daerah perkebunan masyarakat yang diperkirakan masih tercemarioleh limbah cair kelapa sawit. 


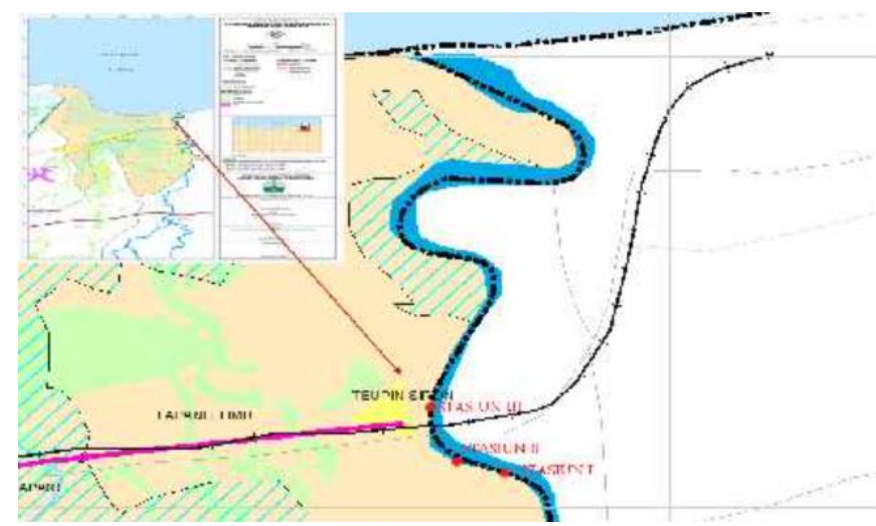

Gambar 1. Peta Lokasi Pengambilan Sampel Air Deskripsi lokasi statiun penelitian

\section{Metode Penelitian}

Untuk pengukuran suhu, kekeruhan dan kecerahan menggunakan metode in situ, untuk mengukur kadar $\mathrm{pH}$, oksigen terlarut, COD dan amoniak mengacu pada baku mutu air dari SNI.06-6989.14 (2009). Metode penelitian yang digunakan mengacu pada Lensun dan Sipriana (2013).

\section{Teknik Pengambilan Sampel}

Pengambilan sampel dilakukan dengan cara memasukkan drum yang telah dimodifikasi dengan pemberat. Drum tersebut dimasukan sampai pada kedalaman yang diinginkan $(0.5 \mathrm{~m}$ dari permukaan perairan dan $0.5 \mathrm{~m}$ dari dasar perairan). drumterisi penuh, maka drum langsung ditarik ke permukaan untuk mengisi drum lain yang telah diberi label.

\section{Pengumpulan dan Analisis Data}

Pengukuran parameter kualitas air dilakukan dengan dua cara yaitu in situ untuk suhu dengan thermometer, kecerahan dengan sechi disc dan kekeruhan dengan menggunakan Turbidity Meter (TU-2016 bante). Untuk oksigen terlarut (DO), pH, kecerahan dan kekeruhan dilakukan di lokasi pengambilan sampel, sedangkan untuk indikator amoniak dan COD dilakukan di laboratorium MIPA Universitas Almuslim, Sampel air diambil pada tiap titik stasiun dengan menggunakan botol. Untuk menjaga jangan sampai terjadi kontaminasi, botol berisi sampel segera diberi label dan dimasukkan dalam coll box berisi es batu. Kemudian sampel dibawa ke laboratorium MIPA Universitas Almuslim untuk dianalisis indikator amoniak dan COD.

\section{Analisis Komponen Utama}

Analisis Komponen Utama adalah metode analisis peubah ganda yang bertujuan memperkecil dimensi peubah asal sehingga diperoleh peubah baru (komponen utama) yang tidak saling berkorelasi tetapi menyimpan sebagian besarinformasi yang terkandung pada peubah asal (Johnson \& Wichern 2002), dalam (Marlince, 2015). Persentase keragaman dianggap cukup mewakili total keragaman jika data $75 \%$ atau lebih. Pembangkitan komponen utama tergantung dari jenis data asal yang digunakan. Apabila data yang digunakan memiliki satuan pengukuran yang sama maka digunakan matriks peragam. Jika syarat di atas tidak terpenuhi, maka digunakan matriks korelasi (Marlince, 2015).

\section{Indeks Pencemaran}

Indeks pencemaran memberikan masukan dalam menilai kualitas badan air untuk suatu peruntukan serta melakukan tindakan untuk memperbaiki kualitas jika terjadi penurunan kualitas akibat kehadiran senyawa pencemaran.

\section{HASIL}

\section{Kualitas Perairan Sungai Krueng Mane}

Setelah melakukan penelitian di perairan sungai Kreung Mane Aceh Utara dengan lokasi yang berjumlah 3 stasiun, maka didapatkan hasil dan analisis parameter fisik kimiaperairan sungai Kreung Mane. Adapun hasil pengukuran dan analisis parameter fisik kimia perairan sungai tersebut disajikan pada tabel 2 dibawah ini:

Tabel 1. Parameter fisik kimia di perairan sungai Kreung Mane Aceh Utara

\begin{tabular}{lllll}
\hline \multirow{2}{*}{ Parameter } & Satuan & \multicolumn{3}{c}{ Stasiun } \\
\cline { 3 - 5 } & & 1 & 2 & 3 \\
\hline $\begin{array}{l}\text { Suhu } \\
\text { Oksigen }\end{array}$ & $\mathrm{oC}$ & 29 & 30 & 30 \\
terlarut & $\mathrm{mg} / \mathrm{L}$ & 6.8 & 6.5 & 5.7 \\
$\begin{array}{l}\text { Kecepatan } \\
\text { Arus }\end{array}$ & $\mathrm{m} / \mathrm{s}$ & 0.3 & 0.1 & 0.1 \\
Kecerahan & $\mathrm{Cm}$ & 75 & 80 & 63 \\
Nitrat & $\mathrm{mg} / \mathrm{L}$ & 0.026 & 0.024 & 0.027 \\
Phospat & $\mathrm{mg} / \mathrm{L}$ & 0.108 & 0.11 & 0.06 \\
pH & - & 8.4 & 8.68 & 8.23 \\
COD & $\mathrm{mg} / \mathrm{L}$ & 48.528 & 87.437 & 70.324 \\
$\mathrm{NH}_{3}$ & $\mathrm{mg} / \mathrm{L}$ & 0.15 & 0.226 & 0.171 \\
\hline
\end{tabular}

Hasil pengukuran suhu yang diamati pada ratarata tiap stasiun diperoleh dengan nilai berkisar antara $29{ }^{\circ} \mathrm{C}-30{ }^{\circ} \mathrm{C}$. Suhu perairan dapat bervariasi tergantung pada beberapa faktor 
yang mempengaruhi. Salah satu faktor yang sangat erat kaitannya dengan adanya pencemaran pembuangan air limbah dan dapat menyebabkan kenaikan suhu perairan sehingga mengganggu kehidupan air. Untuk lebih jelas rata-rata nilai suhu disajikan pada gambar 2 berikut ini:

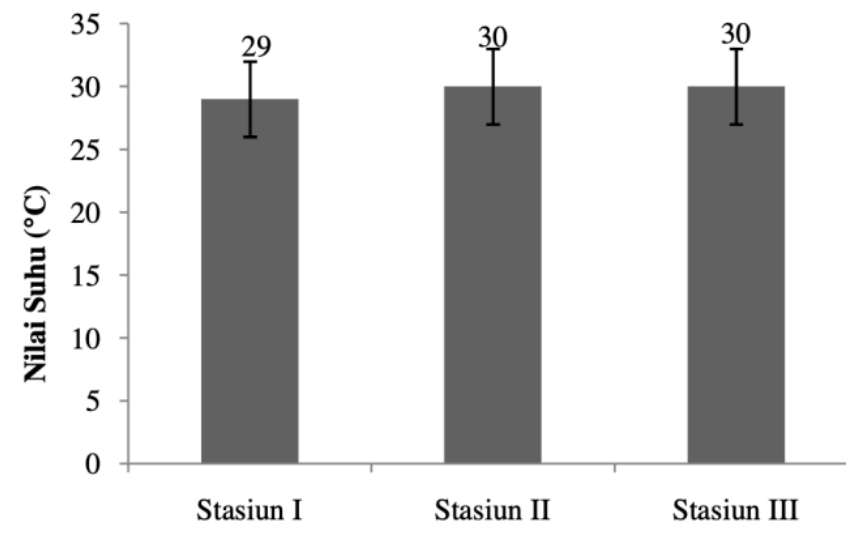

Gambar 2. Rata-rata nilai suhu $\left({ }^{\circ} \mathrm{C}\right)$ di perairan sungai Kreung Mane Aceh Utara

Hasil pengukuran oksigen terlarut yang dilakukan pada rata-rata tiap stasiun diperoleh dengan kisaran nilai antara $5,7 \mathrm{mg} / \mathrm{l}-6,5 \mathrm{mg} / \mathrm{l}$. Untuk lebih jelas rata-rata nilai oksigen terlarut disajikan pada gambar 3 berikut ini:

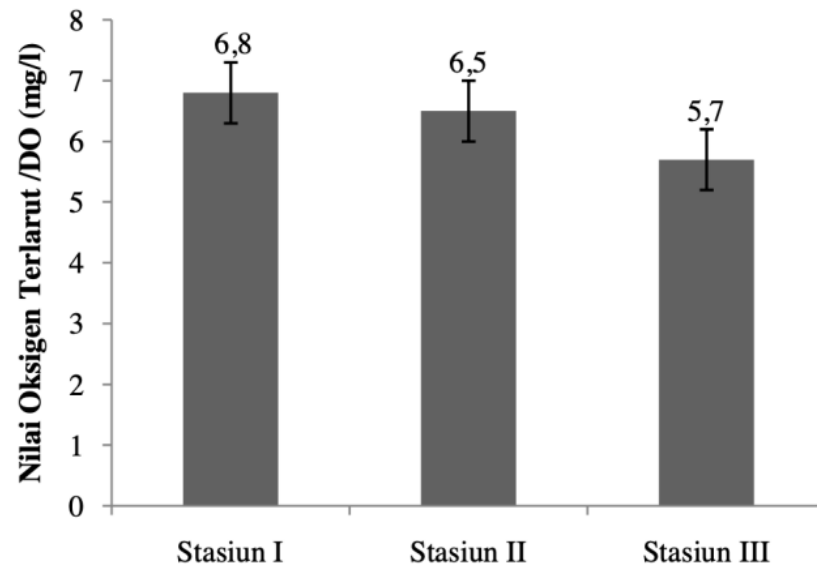

Gambar 3. Rata-rata nilai DO (mg/l) di perairan sungai Kreung Mane Aceh Utara

Hasil pengukuran kecepatan arus yang dilakukan pada rata-rata tiap stasiun diperoleh dengan kisaran nilai antara $0,1 \mathrm{~m} / \mathrm{s}-0,3 \mathrm{~m} / \mathrm{s}$. Untuk lebih jelas rata-rata nilai kecepatan arus disajikan pada gambar 4 berikut ini:

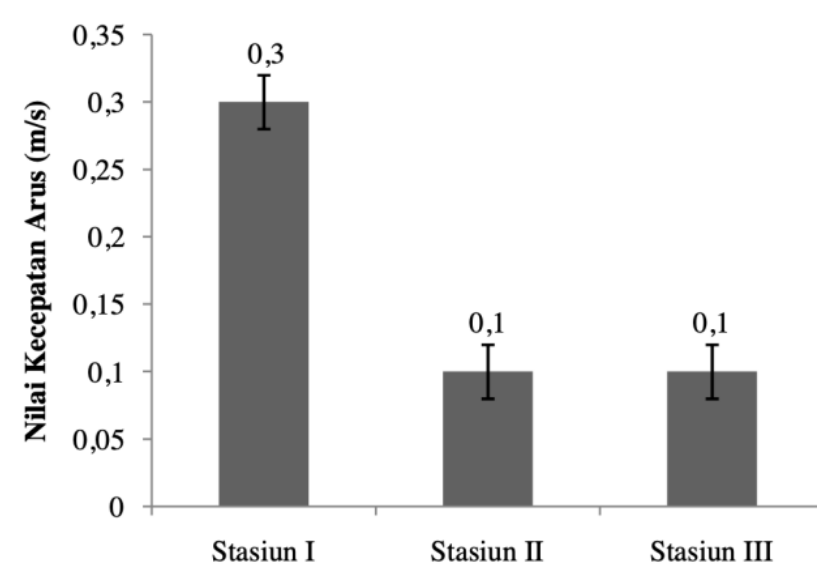

Gambar 4. Rata-rata nilai kecepatan arus (m/s) di perairan sungai Kreung Mane Aceh Utara

Hasil pengukuran kecerahan yang dilakukan pada rata-rata tiap stasiun diperoleh dengan kisaran nilai antara $63 \mathrm{~cm}-80 \mathrm{~cm}$. Untuk lebih jelas rata-rata nilai kecerahan disajikan pada gambar 5 berikut ini:

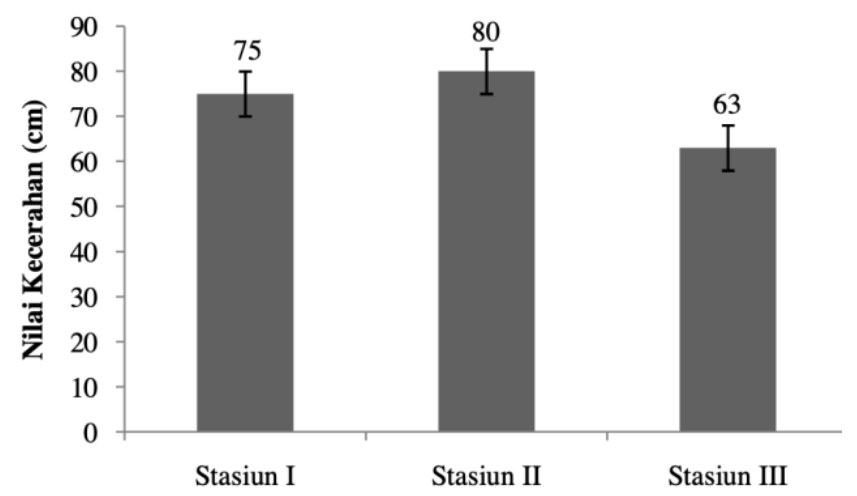

Gambar 5. Rata-rata nilai kecerahan (cm) di perairan sungai Kreung Mane Aceh Utara

Hasil pengukuran nitrat yang dilakukan pada rata-rata tiap stasiun diperoleh dengan kisaran nilai antara $0,024 \mathrm{mg} / \mathrm{l}-0.027 \mathrm{mg} / \mathrm{l}$. Untuk lebih jelas rata-rata nilai nitrat disajikan pada gambar 6 berikut ini:

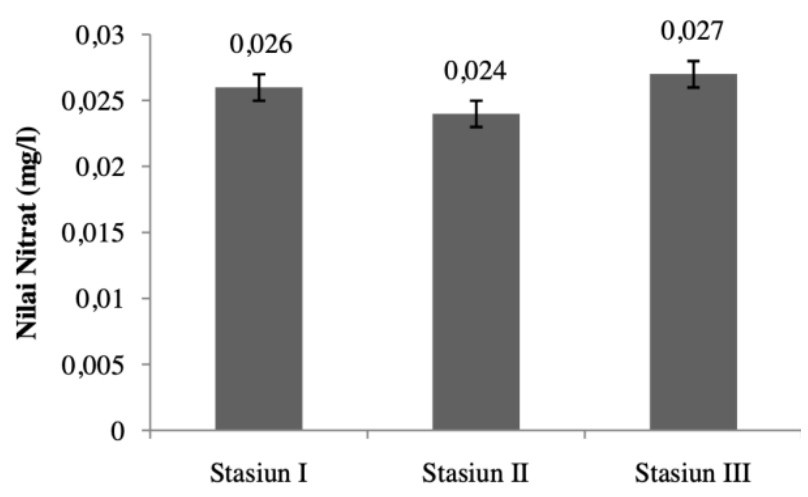

Gambar 6. Rata-rata nilai nitrat (mg/l) di perairan sungai Kreung Mane Aceh Utara 
Hasil pengukuran phospat yang dilakukan pada rata-rata tiap stasiun diperoleh dengan kisaran nilai antara $0,06 \mathrm{mg} / \mathrm{l}-0,11 \mathrm{mg} / \mathrm{l}$. Untuk lebih jelas rata- rata nilai phospat disajikan pada gambar 7 berikut ini:

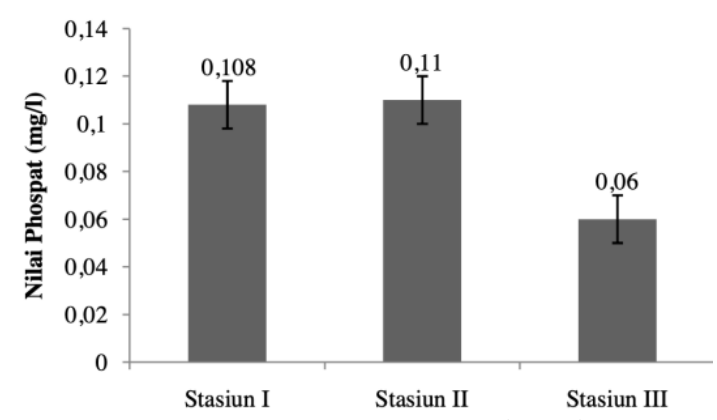

Gambar 7. Rata-rata nilai phospat (mg/l) di perairan sungai Kreung Mane Aceh Utara

Hasil pengukuran $\mathrm{pH}$ yang dilakukan pada ratarata tiap stasiun diperoleh dengan kisaran nilai antara 8,23 - 8,68. Untuk lebih jelas rata-rata nilai oksigen terlarut disajikan pada gambar 8 berikut ini:

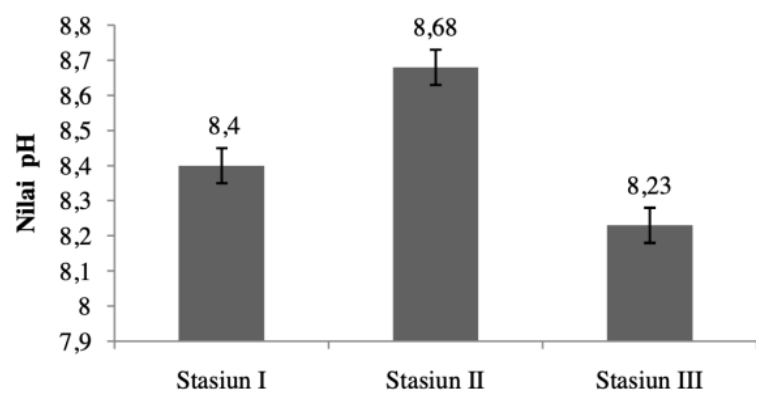

Gambar 8. Rata-rata nilai $\mathrm{pH}$ di perairan sungai Kreung Mane Aceh Utara

Hasil pengukuran Chemycal Oxygen Demand (COD) yang dilakukan pada rata-rata tiap stasiun diperoleh dengan kisaran nilai antara 48,528 mg/l - 87,437 mg/l. Untuk lebih jelas ratarata nilai Chemycal Oxygen Demand (COD) disajikan pada gambar 9 berikut ini:

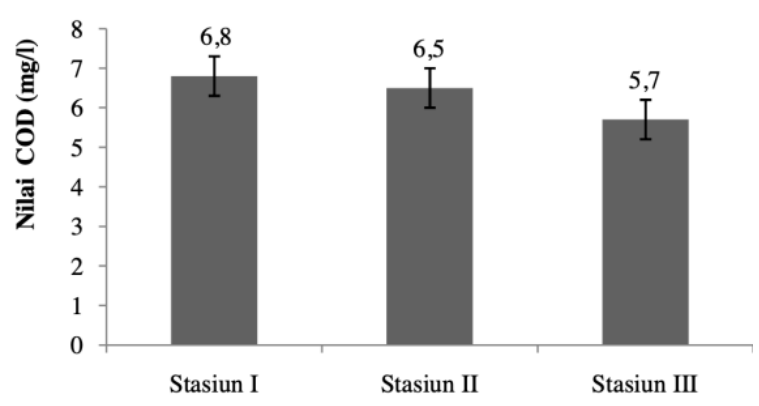

Gambar 9. Rata-rata nilai Chemycal Oxygen Demand (COD) di perairan sungai Kreung Mane Aceh Utara
Parameter fisika-kimia perairan merupakan faktor yang mempengaruhi kehidupandan perkembangan organisme dalam suatu perairan, kualitas perairan baru dapat dikatakan apabila organisme tersebut dapat melakukan pertumbuhan dan perkembangbiakan dengan baik. Organisme perairan dapat hidup dengan layak bila faktor-faktor yang memengaruhinya, seperti fisika-kimia perairan berada dalam batas toleransi yang sesuai dengan kebutuhannya. Hasil analisis pengamatan parameter fisika kimia perairan sungai Krueng Mane Aceh Utara disesuaikan dengan berdasarkan penelitian ilmiah terdahulu. Hasil analisis pengamatan parameter fisika kimia tersebut pada masing masing stasiun disajikan pada Gambar 10 berikut ini:

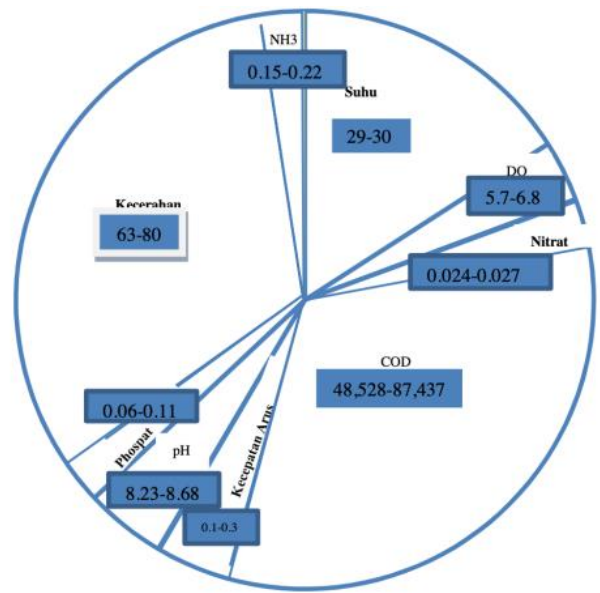

Gambar 10. Analisis komponen utama parameter fisika kimia air.

\section{PEMBAHASAN}

Kondisi suhu air perairan sungai Krueng Mane Aceh Utara saat dilakukan penelitian pada setiap stasiun berkisar antara $29^{\circ} \mathrm{C}-30^{\circ} \mathrm{C}$. Jika dilihat dari kisaran suhu perairan, maka perairan sungai Krueng Mane Aceh Utaramasihpada suhu normal daerah tropis. Menurut Boyd, 2009 dalam Helmi (2013), kisaran suhu di daerah tropis berkisar antara 25-32 ${ }^{\circ} \mathrm{C}$, masih layak untuk pertumbuhan organisme akuatik, sedangkan menurut Huet,1975 dalam Helmi (2013), suhu air yang baik untuk budidaya ikan adalah antar 18,0 $30,0^{\circ} \mathrm{C}$, dengan suhu optimum berkisar $20,0-$ $28,0{ }^{\circ} \mathrm{C}$. Menurut Hermirita (2020), kenaikan suhu menyebabkan lajunya metabolisme dalam tubuh hewan dalam air dan selanjutnya menaikkan kebutuhan oksigen yang mengakibatkan kandungan oksigen dalam air menurun. 
Oksigen terlarut merupakan jumlah oksigen yang diikat olehmolekul air. Dari hasil perhitungan dan analisis bahwa nilai oksigen terlarut (DO) di perairan sungai Krueng Mane Aceh Utara masih dalam keadaan normal. Sesuai pernyataan dari Rahmawati (2011), bahwa kadar oksigen yang digunakan untuk kepentingan perikanan sebaiknya tidak kurang dari $5 \mathrm{mg} / \mathrm{l}$, karena dapat mengakibatkan efek yang kurang menguntungkan bagi hampir semua organisme perairan. Terjadinya proses respirasi mikroba aerob dapat menyebabkan menurunnya jumlah oksigen yang terlarut dalam air.

Kecepatan arus termasuk salah satu paremeter kualitas air yang berpengaruh terhadap kemampuan suatu perairan untuk mengasimilasi dan mengangkut bahan- bahan pencemaran. Menurut Odum (1996) dalam Helmi, 2013, kecepatan arus disungai tergantung kemiringan, kekasaran, kedalaman dan kelebaran dasar perairan. Kemudian Harahap (1991) dalam Helmi, 2013 menjelaskan kecepatan arus dibagimenjadi empat kategori : kecepatan arus $0^{-} 25 \mathrm{~cm} /$ det berarus lambat, kecepatan arus 25- $50 \mathrm{~cm} /$ det berarus sedang, kecepatan arus $50-100 \mathrm{~cm} /$ det berarus cepat, kecepatan arus $>100 \mathrm{~cm} /$ det berarus sangat cepat. Jika dilihat dari kategori kecepatan arus sungai Krueng Mane Aceh Utara termasuk kategori berarussedang. Perairan berarus sedang mempunyai sifat dasar sungai berlumpur dan berpasir, karenadengan arus yang sedang partikel partikel lumpur tidak mudah terbawa oleh arus. Demikian sebaliknyajika perairan memiliki arus yang lambat dasar perairannya akan cenderung berlumpur. Jika dihubungkan dengan keberadaan organisme fitoplankton, maka jenis fitoplankton yang ditemukan pada Stasiun 1, Stasiun 2 dan Stasiun 3 berada pada tengah perairanyang berpasir sementara pada dasar perairan berkerikil dan berlumpur tidak ditemukan. Hal ini menunjukkan bahwa jenis fitoplankton yang menyukai dasar perairan yang berlumpur saja yang bisa bertahan hidup. Muliari et al. (2020) menyatakan bahwa limbah cair kelapa sawit dapat menyebabkan kerusakan pada tahap perkembangan awal ikan nila. Akan tetapi beberapa limbah memberikan dampak positif untuk budidaya seperti limbah budidaya ikan lele berpengaruh terhadap pertumbuhan pertumbuhan populasi Daphnia sp (Akmal et al., 2019).
Nitrat merupakan bentuk nitrogen utama diperairan alami dan nitrat mudah larut dalam air danbersifat stabil, dihasilkan dari proses oksidasi sempurna senyawa nitrogen diperairan. Nitrat adalah nutrient dan nitrat mempercepat tumbuh plankton (Kasry, 2012). Hasil pengamatan nitrat pada setiap Stasiun diperoleh kandungan nitrat tertinggi pada Stasiun 2 yaitu $0,226 \mathrm{mg} / \mathrm{L}$ dan yang terendah $0,15 \mathrm{mg} / \mathrm{L}$, bila dibandingkan dengan baku mutu airkelas I pada PP No. 82 Tahun 2001 (10 mg/L) maka kandungan nitrat masih dibawah ambang baku mutu yang ditetapkan dengan arti kata air sungai Krueng Mane belum tercemar oleh kandungan nitrat. Apabila kita kaitkan dengan tingkat kesuburan air maka air sungai Krueng Mane berdasarkan kandungan nitrat, maka kandungan nitrat pada Stasiun I termasuk perairan yang kurang subur karena kandungan nitratnya di bawah $1,0 \mathrm{mg} / \mathrm{L}$ yaitu $0,15 \mathrm{mg} / \mathrm{L}$, bedasarkan yang dinyatakan oleh Vallenweider dalam Helmi (2011), mengemukakan kriteria kesuburan bedasarkan kandungan nitrat sebagai berikut : $0,0-1,0 \mathrm{mg} / \mathrm{L}$ (perairan kurang subur), 1,0 - 5,0 mg/L (kesuburan sedang), 5,0 $50.0 \mathrm{mg} / \mathrm{l}$ (tingkat kesuburan perairan tinggi). Kualitas air sungai Krueng Mane pada Stasiun 2 dan 3 termasuk perairan yang kurang subur, karena pada ke-2 (dua) Stasiun tersebut kandungan nitrat berada antara $0-1,0 \mathrm{mg} / \mathrm{L}$ yaitu pada Stasiun 2 adalah $0,226 \mathrm{mg} / \mathrm{L}$ dan Stasiun 3 adalah $0,171 \mathrm{mg} / \mathrm{L}$. Sesuai dengan yang dinyatakan oleh Vallenweider dalam Effendi (2003), kandungan nitrat yang mengandung nitrat $0,0-1,0 \mathrm{mg} / \mathrm{L}$ termasuk perairan kurang subur. Kurangnya kandungan nitrat pada Stasiun 1, 2 dan 3 dikarenakan karakteristik lingkungan padake-3 (tiga) stasiun ini hampir sama. Dimana Stasiun 1 ini berada pada daerah bagian hulu Sungai Petapahan dan lebih kurang 100 meter dihulu bendungan irigasi sungai Krueng Mane Aceh Utara. Disamping itu juga kiri kanan sungai bersempadan dengan dan masyarakat, kondisi lingkungan ini akan mengakibatkan terakumulasinya nitrat terutama yang berasal dari limbah domestik.

Berdasarkan hasil penelitian yang dilakukan di perairan sungai Krueng Mane Aceh Utara didapatkan bahwa nilai kandungan phospat berkisar antara 0,06- 0,11 $\mathrm{mg} / \mathrm{L}$. Menurut Alaerts dan Santika dalam Helmi (2011), perairan yang memiliki kadar phospat $<0,01$ $\mathrm{mg} / \mathrm{L}$ memiliki kesuburan perairan yang rendah. 
Kemudian menurut (Yoshimura dalam Helmi (2011), membuat klasifikasi kesuburan perairan berdasarkan kandungan phospat. Apabila kita bandingkan nilai phospat yang berada pada masing masing Stasiun pengamatandengan PP No. 82 Tahun 2001 diperoleh bahwa kandungan phospat pada Stasiun 2 dan 3sudah berada di atas ambang baku mutu yang diperbolehkan, tetapi pada Stasiun 1 kadar phospat telah melebihi ambang baku mutu air kelas I. Hal ini menandakan bahwa pada lokasi tersebuttelah terjadi akumulasi phospat dan senyawa ini akan terurai dengan bantuan oksigen untukdijadikan nutrisi dalam ekosistem.Tingginya kandungan posfat pada Stasiun 1 juga dipengaruhi oleh banyaknya pemberianpupuk phospat seperti pupuk TSP dan pupuk SP 36 untuk kebun karet dan sawit perusahaan dan masyarakat yang berada pada kiri kanan sungai. Kondisi ini juga akan mengakibatkan terakumulasinya phospat di perairan sungai.

Berdasarkan pengukuran $\mathrm{pH}$ pada masing masing Stasiun pengamatan di Sungai Krueng Mane Aceh Utara, diperoleh hasil pH air berada pada kisaran baku mutu yang ditetapkan yang bersifat agak basa dan cocok untuk perairan sungai. Menurut Sastrawijaya (2009) dalam Helmi, (2013) pH air akan menurun suasana asam akibat pertambahan bahan - bahan organik yang kemudian membebaskan $\mathrm{CO} 2$ jika mengurai di dalam air, terjadi perubahan $\mathrm{pH}$ akibat adanya pencemaran oleh bahan - bahan organik, kimia dan lain sebagainya. Tingginya kisaran $\mathrm{pH}$ pada perairan sungai Krueng Mane ini menandakan sungai Krueng Mane bersifat asam. Karena lahan disekitar perairan sungai Krueng Mane bertipe podzolik merah kuning berpasir yang tanahnya bersifat basa. Limbah cair adalah salah satu dampak negatif dari industri pengelolahan kelapa sawit yang dapat menimbulkan gangguan terhadap ekosistem perairan (Akmal et al., 2021)

Namun, ditinjau dari bidang kesehatan $\mathrm{pH}$ air sungai Krueng Mane kurang baik untuk kehidupan makhluk hidup. Air normal yang memenuhi syarat untuk suatu kehidupan mempunyai $\mathrm{pH}$ berkisar antara 6,5- 7,5. Air dapat bersifat asam atau basa tergantung pada besar kecilnya $\mathrm{pH}$ air atau besarnya konsentrasi ion hidrogen dalam air. Air yang mempunyai $\mathrm{pH}$ lebih kecil dari $\mathrm{pH}$ normal akan bersifat asam, sedangkan air yang mempunyai $\mathrm{pH}$ lebih besar dari normal akan bersifat basa. Air limbah dan bahan buangan dari kegiatan industri dan domestic yang mengalir ke sungai akan mengubah $\mathrm{pH}$ air yang pada akhirnya dapat menggangu kehidupan organisme di dalam perairan sungai Krueng Mane.

COD (Chemical Oxygen Demand) erat kaitannya dengan BOD (Biologycal Oxygen Demand). Banyak zat organik yang tidak mengalami penguraian biologi secara cepat, tetapi senyawasenyawa organik itu tetap menurunkan kualitas air. Oleh karena itu perlu diketahui konsentrasi organik setelah masuk dalam perairan sungai melalui uji COD. Kandungan COD di sungai Krueng Mane pada setiap stasiun pengamatan berkisar antara 48,528 $\quad-87,437 \quad \mathrm{mg} / \mathrm{L}$. Kandungan COD yang tertinggi juga dijumpai pada Stasiun 3 yaitu dibagian ujung hulu sungai Krueng Mane yang dekat dengan sumber pencemaran penumpukan bahan - bahan organik. Tingginya COD menunjukkan tingginya akumulasi senyawa organik dan anorganik pada berbagai wilayah dalam perairan sungai Krueng Mane. Hal ini diduga bahwa bersamaan dengan tingginya COD diperairan sungai Krueng Mane, maka nilai BOD juga ikut tinggi pada perairan sungai Krueng Mane tersebut.

\section{KESIMPULAN}

Hasil penelitian yang dilakukan di perairan sungai Krueng Mane Aceh Utara tentang dampak limbah cair kelapa sawit terhadap parameter kualitas perairan sungai Krueng Mane Aceh Utara dapat disimpulkan bahwa parameter kualitas perairan di perairan sungai Krueng Mane Aceh Utara masih termasuk pada kategori pencemaran sedang. Kondisi kualitas perairan sungai Krueng Mane Aceh Utara masih bisa untuk kehidupan makhluk hidup.

\section{DAFTAR PUSTAKA}

Agustiningsih, D., Budi Sasongko, S., \& Sudarno, S. (2012). Analisis kualitas air dan strategi pengendalian pencemaran air Sungai Blukar kabupaten Kendal.

Akmal, Y., Devi, C., Muliari, M., Humairani, R., \& Zulfahmi, I. (2021). Morfometrik sistem pencernaan ikan nila (Oreochromis niloticus) yang dipapar limbah cair kelapa sawit. Jurnal galung tropika, 10(1).

Akmal, Y., Humairani, R., \& Zulfahmi, I. (2019). Pemanfaatan Air Buangan Budidaya Ikan Lele 
(Clarias sp.) Sebagai Media Budidaya Daphnia sp. Jurnal Biosains dan Edukasi, 1(1), 22-27.

Akmal, Y., Humairani, R., Muliari, M., Hanum, H., \& Zulfahmi, I. (2021). Phytoplankton community as bioindicators in aquaculture media Tilapia (Oreochromis niloticus) exposed to detergent and pesticide waste. Akuatikisle: Jurnal Akuakultur, Pesisir dan Pulau-Pulau Kecil, 5(1), 7-14.

Amrizal, A. (2020). Komunitas zooplankton di Sungai Krueng Manee Aceh Utara. Arwana: Jurnal Ilmiah Program Studi Perairan, 2(2), 143-148.

Effendi, H. (2003). Telaah kualitas air, bagi pengelolaan sumber daya dan lingkungan perairan. Kanisius.

Habibi, A. (2020). Komunitas fitoplankton di Sungai Krueng Mane Aceh Utara. Arwana: Jurnal Ilmiah Program Studi Perairan, 2(1), 30-37.

Helmi, Z., \& Anita, S. (2013). Kualitas Sungai Petapahan Kecamatan Gunung Toarkabupaten Kuantan Singingi. Jurnal Kajian Lingkungan, 1(01), 46-58.

Hermirita, S., \& Elvyra, R. (2020). Inventarisasi Jenis-Jenis Ikan Genus Pangasius Di Sungai Kampar Kiri Provinsi Riau. Biospecies, 13(2), 10-15.

Johnson, R. A., \& Wichern, D. W. (2002). Applied multivariate statistical analysis (Vol. 5, No. 8). Upper Saddle River, NJ: Prentice hall.

Kasry, A., \& Sumiarsih, E. (2012). Kesuburan Perairan Waduk Nagedang Ditinjau Dari Kosentrasi Klorofil-A Fitoplankton Desa Giri
Sako Kecamatan Logas Tanah Darat Kabupaten Kuantan Singingi Provinsi Riau. Berkala Perikanan Terubuk, 37(2).

Lensun, M., \& Tumembouw, S. S. (2013). Tingkat Pencemaran Air sungai Tondano di Kelurahan Ternate Baru Kota Manado. E-Journal Budidaya Perairan, 1(2).

Muliari, M., Zulfahmi, I., Akmal, Y., Karja, N. W. K., Nisa, C., Sumon, K. A., \& Rahman, M. M. (2020). Toxicity of palm oil mill effluent on the early life stages of Nile tilapia (Oreochromis niloticus, Linnaeus 1758). Environmental Science and Pollution Research, 27, 3059230599.

Rahmawati, D. (2011). Pengaruh Aktivitas Industri Terhadap Kualitas Air Sungai Diwak di Bergas Kabupaten Semarang dan Upaya Pengendalian Pencemaran Air Sungai (Doctoral dissertation, Program Magister Ilmu Lingkungan).

Republik Indonesia. (2011). Peraturan Pemerintah Nomor 38 Tahun 2011 tentang Sungai.

Syafriadiman, S. (2016). Toksisitas Limbah Pabrik Minyak Kelapa Sawit Terhadap Benih Ikan Nila Merah (Oreochromis sp.). Jurnal Perikanan dan Kelautan, 21(1), 25-32.

Tamonob, A. M., Saefuddin, A., \& Wigena, A. H. (2015). Nonlinear Principal Component Analysis and Principal Component Analysis with Successive Interval in K-Means Cluster Analysis. In Forum Statistika Dan Komputasi, 20(2). 